\title{
PURSUIT OF NON-PECUNIARY LOSS AND PECUNIARY DAMAGE COMPENSATION FOR SPOILED HOLIDAY
}

\author{
Joanna May*
}

\begin{abstract}
Since $1^{\text {st }}$ July, 2018, the provisions of the $24^{\text {th }}$ November, 2017 Act on package travel and linked travel arrangements, which deals with the rights of wronged tourists under the so-called spoiled holiday have been in force. The Act on package travel replaced the previous regulation, resulting from the $29^{\text {th }}$ August 1997 Act on hotel tour leaders and tourist guides services, introducing a much broader scope of liability for entrepreneurs operating in the tourism industry, which was to facilitate the pursuit of claims. The article presents the method of repairing damage for the loss of pleasure from vacation in the previous and applicable legal status. Then, the author presents the course of court proceedings, both when the traveller decides to take group proceedings, as well as when he/she individually brings an action. The author draws attention to the need for the traveller to properly prepare for the civil proceedings due to the burden of proof on him/her, and also discusses the advantages and disadvantages of certain legal solutions.
\end{abstract}

Key words: wasted holidays, loss of vacation pleasure, lost leisure, compensation, damages, the pursuit of claims, compensation for non-pecuniary damage, improper performance of the contract

Ph.D. Assistant Professor in the Chair of Civil Law and Civil Proceedings Law, Nicolaus Copernicus University in Toruń, jmay@umk.pl, ORCID: 0000-0001-8660_ 0784 . 


\section{INTRODUCTION}

The current $24^{\text {th }}$ November 2017 Act on package travel and linked travel arrangements ${ }^{1}$ implements into national law the provisions of Directive (EU) on package travel and linked travel arrangements 2015/2302 of the European Parliament and of the Council of $25^{\text {th }}$ November 2015, amending Regulation (EC) No. 2006/2004 and Directive 2011/83/EU of the European Parliament and of the Council and repealing Council Directive $90 / 314 / \mathrm{EEC}^{2}$. The new law deals with the tour operator's liability for the provision of travel arrangements, at the same time setting out the claims vested in the traveller for "spoiled holidays" or else verba legis for non-compliance with the contract, which shall be understood as the failure to perform or improper performance of travel arrangements covered by the package travel (Article 4 point 16).

From the point of view of current regulations, it is hard to believe that no more than two decades earlier, there occurred many legal problems against the background of the so-called travel contracts, among other things, linked to compensation claims for non-performance or improper performance of the contract. Difficulties were caused by pursuing claims for compensation of damage referred to as "loss of holiday pleasure", "lost leisure time" or "spoiled (lost) holiday", and in more detail, their legal qualification. Regardless of the travel damage which could arise - as a result of failure or improper performance of the travel contract by the tour operator - non-pecuniary loss has occurred also nearly in every case. The legal classification of pecuniary damage, resulting from the irregular performance of the travel contract raised no doubt, however, the juridical recognition of non-pecuniary loss, whose claims were focused on various facts was doubtful.

The purpose of the paper is to outline the procedural and substantive law aspects of claims for damages for spoiled holidays. Substantive law issues were presented only to the extent necessary to present the title issue.

J. of L. of 2019, item 548 referred to hereinafter as Act on package travel.

2 Official Journal EU L 326 of 11.12.2015, p. 1. 


\section{COMPENSATION OF NON-PECUNIARY LOSS AND DAMAGE OF SPOILED HOLIDAYS}

\subsection{Claims for spoiled holidays}

Compensation claims for non-performance or improper performance of a travel contract include both a claim for pecuniary damage compensation and for compensation of non-pecuniary loss. The qualification of individual forms of damage can give rise to doubts.

A claim for compensation of pecuniary damage includes the real damage to property (damnum emergens) and lost profits (lucrum cessans). On principle, a pecuniary damage is accompanied by a non-pecuniary loss. As an example, costs can be calculated e.g. lower standard of accommodation, cancellation of one of trips while package stay, purchase of airline tickets in other airlines, so as to return to the country as soon as possible, or purchase of clothes when the luggage does not reach the place of destination whose refund will not compensate for the loss of holiday pleasure ${ }^{3}$. The provision which allows to seek compensation of contractual liability was Art. 471 of the C.C., however, it was not easy to deal with non-pecuniary loss ${ }^{4}$.

In the doctrine, there was ongoing discussion whether the lost holiday pleasure shall be classified as pecuniary damage or non-pecuniary loss. Including a spoiled holiday to the second of these categories raised further questions, namely, is the traveller entitled to compensation of non-pecuniary loss? Depending on the legislation, this legal issue was solved differentlys.

3 M. Ciemiński (2005), Naprawienie uszczerbku polegającego na utraconej przyjemności z podróży [Redress of detriment consisting in loss of pleasure at spoiled holiday], Kwartalnik Prawa Prywatnego [Quarterly], No. 2: 359 et seq.

4 Confer: M. Nesterowicz (1988), Glosa do uchwały z dnia 25 lutego 1986 r., III CZP 2/86, [Gloss to resolution of $25^{\text {th }}$ Febr. 1986], Nowe Prawo, No. 9: 114; M. Ciemiński, Naprawienie..., 364 et seq.

5 I. Kuska-Żak (2008), Odpowiedzialność organizatora turystyki za szkodę niemajątkową powstałą na skutek niewykonania lub nienależytego wykonania umowy o imprezę turystyczną [Tourism organizer's liability for non-pecuniary compensation in case of non-performance or improper performance of travel package contract], In: P. Cybula, J. Raciborski, ed., Turystyka a prawo. Aktualne problemy legislacyjne i konstrukcyjne 
Compensations of non-pecuniary loss were paid in those countries where the courts are free to decide on compensation (France, Belgium, Spain), while in other legal systems, as Poland for instance, where compensation of non-pecuniary loss can only be claimed in the cases laid down in the Act, such travellers' claims have never been taken into consideration (Germany, Austria, Greece, the Netherlands).

In German jurisprudence, this problem was solved in such a way that it was assumed that the claim for spoiled holiday is of a pecuniary nature. Since acknowledging the non-pecuniary nature of this claim would close the way for travellers to pursue claims, as pursuant to $\$ 253 \mathrm{Abs}$. 1 Bürgerliche Gesetzbuch $(\mathrm{BGB})^{7}$ compensation of non-pecuniary loss/damage (immaterieller Schaden) can be granted only in the cases specified in the Act, and before the implementation of EU Council Directive 90/314/ EEC of 13 June 1990 such a basis did not exist ${ }^{8}$. In Austria, it was only after the implementation of Council Directive 90/314/EEC that it was recognized admissible to claim for non-pecuniary loss, arising from spoiled holidays. The judgment of the Court of Justice of $12^{\text {th }}$ March 2002 in the case of Simone Leitner v. TUI Deutschland GmbH \& Co. KG rendered as a result of a pre-judicial question from the Linz Regional Court (Landesgericht Linz) was a breakthrough for the proper interpretation of Art. 5 of the Directive. In answer to the question, the Court of Justice stated that Art. 5 of Directive 90/314/EEC granted consumers the right to compen-

[Tourist travels and law. Current legislation and construction issues], Sucha BeskidzkaKraków, 125 et seq.; M. Nesterowicz (2011), Odpowiedzialność cywilna biura podróży za "zmarnowany urlop" w prawie polskim i porównawczym [Liability of travel agencies for spoiled holiday in Polish and comparative law] [at the background of the Supreme Court's resolution of 19 $9^{\text {th }}$ Nov. 2010], Przegląd Sądowy, No. 5: 5 et seq.; M. Nesterowicz (2011), Odpowiedzialność cywilna biur podróży w prawie francuskim [Liability of travel agencies in French law], Państwo i Prawo, No. 2: 34 et seq.

6 Confer: M. Nesterowicz, Gloss..., 114. Confer also M. Nesterowicz (2002), Zadośćuczynienie pieniężne za "zmarnowany urlop" podczas wycieczki turystycznej [Pecuniary compensation for spoiled holiday at a package travel], Państwo i Prawo, No. 10: 73.

7 German Civil Code of $18^{\text {th }}$ August 1896 (Bürgerliche Gesetzbuch).

8 More, confer: M. Nesterowicz, Zadośćuczynienie..., 73, 75. 
sation of non-pecuniary loss, resulting from non-performance or improper performance of the service in the form of package holidays 9

There have been no restrictions in the contractual liability regime in French law. Therefore, any damages resulting from debtor's breach of contract, regardless of their material or non-pecuniary nature, were subject to compensation. As a result of the implementation of Directive 90/314/ EEC, the French legislator, in lieu of liability of a travel agency on the basis of fault, introduced liability on a risk basis (le responsabilité de plein droit) ${ }^{10}$.

Currently, in the literature on the subject matter, the non-pecuniary nature of damage in the form of "spoiled holidays" does not give rise to doubt any more ${ }^{11}$. As is rightly emphasized in the doctrine, there is no detriment to the property of the wronged party caused in this respect; it is also obvious that the pleasure anticipated in connection with the travel (spoiled holidays), and not obtained as a result of non-performance or improper performance of the concluded contract, remains only in the sphere of the traveller's sensations and feelings, so it is a purely mental phenomenon, devoid of any material or commercial element ${ }^{12}$.

The essence of compensation of non-pecuniary loss is to compensate the non-pecuniary damage, consisting in the loss of pleasant moments anticipated in connection with the conclusion of the contract, usually associated with travel, relaxing and leisure. The amount of compensation of non-pecuniary loss is an individual matter and each time depends on the assessment of the impact of the inconvenience suffered on the traveller's mental sphere and well-being, because just like every traveller has different

9 Judgement of the Court of Justice of the European Union of $12^{\text {th }}$ March 2002, case No. C-168/00, Legalis No. 61534.

10 M. Nesterowicz, Odpowiedzialność cywilna biur podróży w prawie francuskim, Państwo i Prawo 2011, No. 2: 40; K. Kryla-Cudna, Zadośćuczynienie pieniężne za szkodę niemajątkową powstałą wskutek niewykonania lub nienależytego wykonania umowy, Warszawa 2018, 220 et seq.

11 J. Luzak, K. Osajda (2005), Odpowiedzialność za zmarnowany urlop w prawie polskim [Liability for spoiled holiday in Polish law], Kwartalnik Prawa Prywatnego, No. 2: 306 et seq.; M. Botiuk-Filip (2019), Problematyka odpowiedzialności turystycznych biur podróży za poniesione przez podróżnych szkody majątkowe i niemajątkowe [Problems of travel agencies' liability for pecuniary and non-pecuniary damage incurred by travellers], Przegląd Ustawodawstwa Gospodarczego, No. 3: 16 et seq.

12 SC's resolution of 19.11.2010, III CZP 79/10, Legalis No. 260723. 
expectations for the holiday, thus also other circumstances can ruin their holiday. In some cases, the damage to non-pecuniary goods estimated in this way, translated into the amount of compensation of non-pecuniary loss can go beyond the value of the services purchased.

\subsection{Compensation of spoiled holiday damage in previous and current legal status}

In consequence of the view, which was well-established under Art. 157 $\$ 3$ of the Code of Obligations ${ }^{13}$ that compensation of non-pecuniary loss can be demanded only in the cases set out in the Act ${ }^{14}$, originally, the legal basis for compensation of non-pecuniary loss for "spoiled holiday" was sought in Art. 56 of the C.C., and then, the existing instruments for the protection of personal rights were applied so that after fulfilling the other prerequisites of liability, it was possible to award damages pursuant to Art. 445 or 448 of the C.C. ${ }^{15}$ In the literature on the subject, attempts to construe the right to undisturbed rest as a personal good have been made ${ }^{16}$. In its jurisprudence, the Supreme Court has repeatedly emphasized that the protection of personal rights is unique and the artificial extension of the catalogue of these goods is unjustified ${ }^{17}$. In the opinion of the Supreme Court, the right to peaceful rest (holiday) is not a personal good that falls within the catalogue of goods contained in Art. 23 of the C.C., although the conduct of the tourism organizer, leading to "spoiled holiday", can

13 L. Peiper (1934), Kodeks zobowiązań [The Law of Contracts], Kraków, 206, 208.

14 Similar solutions function in Germany ( $\$ 253$ Abs. 1 BGB), Austria ( $\$ 1293$ Abs. 1 ABGB), Greece, the Netherlands. As to France, Belgium and Spain, their courts are free to allow non-pecuniary loss compensation which depends on the court's discretion. More, confer: M. Nesterowicz, Zadośćuczynienie [Pecuniary], 73.

15 Thus S.C. in its resolution of 19.11.2010, III CZP 79/10, Legalis No. 260723.

16 Confer: G. Siedlecki (2014), Zadośćuczynienie za zmarnowany urlop [Non-pecuniary loss compensation for spoiled holiday], Studenckie Zeszyty Naukowe, No. 24: 42 et seq.; P. Zasuwik (2016), Odpowiedzialność organizatora turystyki za szkodę niemajątkową klienta w postaci tzw. zmarnowanego urlopu [Tourism organizer's liability for non-pecuniary loss in form of so-called spoiled holiday) - gloss - III CZP 79/10, Monitor Prawniczy, No. 24: 1329 et seq.

17 SC's resolution of 19.11.2010, III CZP 79/10, Legalis No. 260723. 
breach personal rights, for example, listed in Art. 24 of the C.C., including in particular health, integrity or personal freedom ${ }^{18}$.

The situation changed after the entry into force of the $29^{\text {th }}$ August 1997 Act on hotel tour leaders and tourist guides services ${ }^{19}$. Article 11a introduced by this Act was the equivalent of art. 5 subparagraphs 1 and 2 of Directive 90/314/EEC ${ }^{20}$, which laid down the tour operator's liability for damage caused to a traveller as a result of non-performance or improper performance of the contract ${ }^{21}$. Pursuant thereto, in its $19^{\text {th }}$ November 2010 resolution, the Supreme Court decided that Art. 11a subparagraph 1 of the Act on package travel may make up the grounds for the tour operator's liability related to non-pecuniary loss of the traveller in form of the so-called spoiled holiday ${ }^{22}$. The tour operator's liability has its source in the contractual liability, which means that it includes not only the obligation to compensate the pecuniary damage ${ }^{23}$. In accordance with Art. 11a subpara. 1 of the Act on package travel, the tour operator is liable for the non-performance or improper performance of the contract related to the provision of package travel, unless the non-performance or improper per-

18 Thus SC in judgement of 24.03.2011, I CSK 372/10, Legalis No. 354220. Confer also Warsaw Appellate Court's judgement of 29.04.2013, VI ACa 1357/12, Legalis No. 1049404.

19 J. of L. of 2017, item 1553, referred to hereinafter as the Act on package travel.

20 Directive of the Council No. 90/314/EEC of $13^{\text {th }}$ June 1990 on package travel, package holidays and package tours [Official Journal of EU L 158, p. 59). More, confer: M. Nesterowicz (1996), Dyrektywa Rady Wspólnot Europejskich o podróżach turystycznych a prawo polskie [Directive of the Council of the European Communities on package travel and Polish law], Kwartalnik Prawa Prywatnego, No. 3: 435 et seq.; E. Bagińska, A. Osowska-Kowalska (2013), Dyrektywa 90/314/EWG o podróżach turystycznych perspektywy zmian [Directive on package travel 90/314/EEC - prospects of changes], In: M. Nesterowicz, ed., Odpowiedzialność biur podróży a ochrona klientów w prawie polskim i Unii Europejskiej [Travel agencies' liability and protection of travellers in Polish and European Union Laws], Toruń, 23 et seq.

21 Confer: M. Nesterowicz, Zadośćuczynienie..., 73.

22 SC's resolution of 19.11.2010, III CZP 79/10, Legalis No. 260723. See also: the SC's judgement of 24.03.2011, I CSK 372/10, Legalis No. 354220.

23 The SC's 19.11.2010 resolution expresses (by the pro-Union interpretation which allows to achieve the intermediate effect of the directive's application) the idea of mitigating the result of non-full implementation by Polish legislator of all regulations, arising from Directive 90/314 - thus P. Zasuwik, Odpowiedzialność..., 1332. 
formance is caused exclusively by the customer's acting or omission to act, acting or omission to act of others, not participating in the performance of the services provided for in the contract, if this acting or omission to act could be neither forecast nor avoided or in the case of force majeure ${ }^{24}$.

The exclusion of liability for non-performance or improper performance of the contract, however, did not release the tour operator from the obligation to assist the wronged customer during the package travel. Article 11a of the Act on package travel, to the extent that it permitted compensation of damage caused by non-performance or improper performance of a package travel contract, was a special provision in relation to Art. 471 of the C.C. The provisions of the C.C. applied to the liability for non-performance or improper performance of travel contract only to the extent not dealt with in the Act on package travel ${ }^{25}$.

The $19^{\text {th }}$ November, 2010 resolution of the Supreme Court ${ }^{26}$ dispelled doubts that arose with regard to the Polish legislator having implemented incompletely the regulations, resulting from Directive 90/314/EEC ${ }^{27}$. In Art. 11a of the Act on package travel, the legislator created an independent, autonomous basis for contractual liability, based in the regulation of EU law ${ }^{28}$.

Since $1^{\text {st }}$ July, 2018, the provisions of the $24^{\text {th }}$ November, 2017 Act on package travel and linked travel arrangements ${ }^{29}$, which deals with the rights of wronged tourists under the so-called spoiled holiday have been in

24 Due to the implementation of Directive (EU) on package travel and linked travel arrangements 2015/2302 of the European Parliament and of the Council of $25^{\text {th }}$ November, 2015, similar legal solutions regarding compensation for wasted holidays will operate in the Member States. Para. 651n BGB, effective since $1^{\text {st }}$ July, 2018, may be an example.

25 Confer: M. Nesterowicz, Zadośćuczynienie..., 72.

26 SC's resolution of 19.11.2010, III CZP 79/10, Legalis No. 260723.

27 The recognition that the relevant regulation which would allow to pursue claims for spoiled holiday is missing in Polish legislation would give rise to the liability of the State for the damage incurred as effect of non-implementation or faulty implementation by the Member State of Directive 90/314/EEC. Thus: M. Ciemiński, Naprawienie..., 358; E. Bagińska, A. Osowska-Kowalska, Dyrektywa..., 25 et seq.

28 SC's resolution of 19.11.2010, III CZP 79/10, Legalis No. 260723. Confer: also the statement of reasons for a draft bill to amend the $29^{\text {th }}$ August 1997 Act on tourist services, Parliament of Tenure of Office III, published in print No. 2089.

29 J. of L. of 2019, item 548. 
force. The Act in force transposes into the national legal order the provisions of $25^{\text {th }}$ November, 2015 2015/2302/EU Directive of the European Parliament and of the Council on package travel and linked travel arrangements, amending Regulation (EC) No. 2006/2004 and the Directive of the European Parliament and of the Council 2011/83/EU and repealing Council Directive 90/314/EEC ${ }^{30}$. The Act on package travel have replaced the previous regulation, resulting from the Act on package travel ${ }^{31}$, introducing a much broader scope of liability for entrepreneurs operating in the tourism industry, which was to facilitate the pursuit of claims. Pursuant to Art. 50 subpara. 2 of the Act on package travel, the traveller is vested with the right to compensation for any damage or harm sustained as a result of non-compliance. The tour operator can be released of their liability if they prove that: 1) the traveller is at fault for the non-compliance; 2) another party, unrelated to the provision of travel services covered by the contract for the package travel is at fault and the non-compliance was unforeseeable and unavoidable; 3) the non-compliance was caused by unavoidable and extraordinary reasons.

Mirosław Nesterowicz rightly draws attention to the incorrect implementation of the Directive ${ }^{32}$. As he notes, points 1 and 2 of Art. 50 subpara. 3 of the Act on package travel, introduce the fault of the traveller and the fault of a third party as conditions to exclude the responsibility of the tour operator, in breach of Directive 2015/2302. Article 14 subpara. 3 of the Directive refers to a non-compliance which may be attributed to a traveller or a third party unrelated to the provision of travel services covered by the contract, not to their fault ${ }^{33}$. Thus, if Art. 14 subpara. 3 of the Directive does not mention fault, in this case, while interpreting the

30 More: M. Nesterowicz (2018), Dyrektywa Unii Europejskiej o imprezach turystycznych i powiązanych usługach turystycznych, jej implementacja do prawa polskiego i odpowiedzialność biur podróży [Directive of the European Union on package travel and linked travel arrangements its implementation into Polish law and liability of travel agencies], Przegląd Sądowy, No. 9: 44-57.

31 J. of L. of 2017, item 1553.

32 M. Nesterowicz (2018), In: Prawo zobowiązań - część szczegółowa [The Law of Contracts - special part], System Prawa Prywatnego [Private Law System). Vol. 7, J. Rajski, ed., Warszawa, 1181 et seq.

33 Thus M. Nesterowicz, In: Prawo zobowiązań..., 1181 et seq. 
Directive strictly, the act or omission of the traveller or a third party does not need to be at fault. In such a situation, examining a particular case the court shall apply the Directive, not Polish law, or refer to the Court of Justice a question for a preliminary ruling on the interpretation of Art. 14 subpara. 3 of this Directive in conjunction with Art. 50 subpara. 3 of the Act on package travel ${ }^{34}$.

\section{PURSUIT BY TRAVELLERS OF CLAIMS FOR SPOILED HOLIDAY}

\subsection{General comments}

In practice of applying the law, the legal basis for pursuing non-pecuniary claims for spoiled holiday raises no doubt any more. The traveller does not have to be afraid that the court will dismiss their action, considering that their claim has no legal justification ${ }^{35}$, however, this does not mean that obtaining non-pecuniary loss compensation or even pecuniary damage compensation in this respect is an easy task.

It needs to be kept in mind that the pursuit of claims in a civil trial, which is adversarial, is primarily related to demonstrating evidence. Regardless of the need to prove the reasons for the claim pursued, first of all, the traveller shall decide which claim they want to assert, whether they want to claim damages, or compensation of non-pecuniary loss, as well as who is the defendant in case of their claims. When deciding to file a claim for compensation of non-pecuniary loss for spoiled holiday, the choice remains between out-of-court proceedings, mediation included ${ }^{36}$, and judicial trial proceedings. The traveller may bring an action individually or decide to participate in group proceedings. The traveller can choose group proceedings, if they find out that pursuing a claim in such proceedings is

34 M. Nesterowicz, In: Prawo zobowiązań..., 1182.

35 Confer: M. Nesterowicz, Gloss..., 113 et seq.

36 More thereon: K. Gajda-Roszczynialska (2012), Sprawy o ochronę indywidualnych interesów konsumentów w postępowaniu cywilnym [Cases for protection of individual consumers' rights], Warszawa, 408 et seq. 
more favourable than an individual action, for instance because of court costs, e.g. when suing the tour operator for very small claims ${ }^{37}$.

Since $1^{\text {st }}$ July, 2018, i.e. since the Act on package travel entered into force, the traveller has had three years to seek redress, without the need to apply the complaint procedure (Article 50 subpara. 4 of the Act on package travel). Under the previously applicable Act on package travel, it was necessary, notwithstanding immediate notification of defective performance of the contract, to file a complaint within 30 days of the end of the package travel (Article $16 \mathrm{~b})^{38}$. It was a strict time limit and as a consequence, the failure to comply therewith resulted in the dismissal of the claim ${ }^{39}$.

\subsection{Claims in group proceedings}

Group proceedings are civil proceedings, although the provisions of the Code of Civil Proceedings apply thereto accordingly only to the extent not covered by the Act on claims pursuing in group proceedings of $17^{\text {th }}$ December, $2009^{40}$.

Group proceedings have several significant differences from the so-called ordinary civil proceedings. First of all, group proceedings are admitted, if the conditions for these proceedings admissibility are cumulative, both as to their subject and object. These prerequisites include the same type of claims of group members, the identity or the sameness of factual grounds for the group members' claims, the number of the group members (minimum 10 people), the unification of monetary

37 Thus M. Sieradzka, Dochodzenie roszczeń w postępowaniu grupowym [Claims pursuit in group proceedings], Warszawa 2018, 33.

38 P. Piskozub (2015), Reklamacja imprezy turystycznej [Claim against a package travel], Edukacja Prawnicza, No. 1: 22 et seq.; K. Maciąg (2018), Ochrona podróżnego na tle ustawy o imprezach turystycznych i powiązanych usługach turystycznych oraz ustawy o usługach turystycznych - analiza porównawcza [Traveller's protection at the background of the Act on package travel and linked travel arrangements - comparative analysis], IKAR, No. 4, Legalis.

39 More: M. Nesterowicz, Prawo turystyczne [Tourist Law], Warszawa 2016, 117 et seq.

40 J. of L. of 2018, item 573, hereinafter referred to as group proc. 
claims, and the features of claims which allow them to be cognized in group proceedings $s^{41}$.

In group proceedings, different in their course from the so-called ordinary civil proceedings, three phases can be distinguished: the first one starts when the claim is filed and ends when the decision to examine the case in group proceedings (Article 6 , Article 10 of the Act on-group proc.) is taken, the second phase initiated by the announcement of the group proceedings being started, consists in the final setting out the composition of the group (Article 11, Article 17 of the Act on-group proc.), while the third phase of the proceedings focuses on the examination of the case and ends, awarding a judgment which, after becoming of force of law, has effect towards all members of the group (Article 21 subpara. 3 of the Act on-group proc. ${ }^{42}$. Cases that qualify for consideration in group proceedings are heard by the regional court composed of three professional judges (Article 3 of the Act on-group proc.).

Cases for compensation of non-pecuniary loss and damage of spoiled holiday belong to subject matters of group proceedings (Article 1 subpara. 2 of the Act on-group proc.), however, at least 10 people are required to file the group proceedings and pursue together one type of claims based on the same or on the same kind of factual basis. While meeting the admissibility conditions for group proceedings of the same type claims of group members, the identity or the sameness of the factual basis would not be difficult to be met for travellers who took part in the same travel, it could be difficult to make the amounts of group members' claims uniform. The simplest way to make the claims of group or subgroup (with a minimum of 2 people) members equal is to reduce their value, which would generally mean giving up a part of the claims by those whose claims are higher. The value of group proceedings is undoubtedly their lower cost (Article 13d of the ACCCC), which additionally is spread out over a larger number of people pursuing

41 Thus the Warsaw Regional Court in decision of 24.7.2013, XX GC 1004/12, Legalis No. 1559969.

42 M. Asłanowicz (2019), Ustawa o dochodzeniu roszczeń w postępowaniu grupowym [Act on claims pursuit in group proceedings]. Komentarz, Warszawa, commentary to Art. 1, theses $8-11$. 
their claims ${ }^{43}$. In addition, a group representative and the barrister, acting on behalf of the group (Art. 4 of the Act on-group proc.), along with the other group members not being active in group proceedings, which may also be an incentive to use this form of pursuing the compensation ${ }^{44}$.

In cases of monetary claims, it is also possible to bring a group action in which the claim is limited to setting out the defendant's liability for a specific event or events. In this case, the claimant need not prove their legal interest to establish the right. The court, allowing the claim to determine the defendant's liability for a given event or events, establishes the circumstances common to the members of the group which make up the prerequisites for the claims they pursue (Article 2 subpara. 3 and 4 of the Act on group proc.). Such a judgment, determining the liability of the defendant, facilitates the claimants to pursue claims in individual proceedings ${ }^{45}$.

\subsection{Claims in so-called ordinary proceedings}

If the traveller decides to pursue compensation in court proceedings, the compensation of non-pecuniary loss or of pecuniary damage for spoiled holiday qualifies to be cognized in a civil proceedings court trial.

43 Pursuant to Art. $13 \mathrm{~d}$ of the $28^{\text {th }}$ July 2005 Act on court costs in civil cases (J. of L. of 2019, item 785 hereinafter referred to as ACCCC) in cases for pecuniary rights pursued in group proceedings, the standing fee or value-related fee amounts to one half of the fee set out pursuant to Art. 13, Art. 13a and Art. 13b, however, to not less than PLN 100 and to not more than PLN 200 000. In cases heard in group proceedings, the group representative who initiates the action shall request the court to set out a temporary fee from the action. In accordance with Art. 15 subpara. 2 of the ACCCC, the temporary fee is set out, ranging from PLN 300 to PLN 20 000. Such a request missing, this shall have such an effect that every change within the group members will require paying a supplementary fee on the action when new members join the action. Thus D. Szostek, In: J. Gołaczyński, D. Szostek, ed., (2019), Kodeks postępowania cywilnego [The Code of Civil Proceedings]. Komentarz do ustawy [Commentary to the 4.7.2019 Act on amendments to the Law - The Code of Civil Proceedings and some other laws], Warszawa, commentary to Art. 13d of the ACCCC thesis 4.

44 A. Tomaszek (2010), Pełnomocnik powoda w polskim postępowaniu grupowym [Claimant's representative in Polish group proceedings], Monitor Prawniczy, No. 12: 667 et seq.

45 Judgement of Poznań Appellate Court of $12^{\text {th }}$ December 2017, I ACa 632/17, Legalis No. 1717465. 
The civil proceedings are divided into ordinary proceedings and separate proceedings. As a rule, cases are heard in proceedings run on general principles, called ordinary proceedings, to distinguish them from separate ones dealt with in the CCP.

A traveller can make claims for spoiled holiday on their own, although the most common in the case law of common courts are the claims for compensation filed by several travellers, which is understandable, as the claim for compensation is most frequently filed by family or friends who spent their holidays together. Then, owing to one action being filed against the organizer of tourism, formal joint co-participation takes place on behalf of the claimant. In accordance with Art. $72 \$ 1$ point 2 of the CCP the formal joint co-participation occurs when one type claims or obligations are based on the same factual and legal basis, if, moreover, the court's jurisdiction is justified for each claim or liability separately, as well as for all of them jointly (formal joint co-participation). In this case, each traveller claims exclusively their pecuniary or non-pecuniary claim or else both of them at the amount laid down by them. This is undoubtedly a convenient solution owing to the chance of cooperating between the claimants and although each of the co-participants bears the process costs related to their participation in the proceedings, some of the costs, spread over several claimants, will be obviously lower, such as expenditure on evidence of an expert opinion or remuneration for one barrister retained by all formal participants.

The course of civil proceedings with regard to compensation of spoiled holiday does not differ from other compensation processes, however, the specificity of the subject matter of the travel contract has it that it requires the process to be prepared with due care, in particular in the field of evidence.

4. THE COURSE OF SO-CALLED ORDINARY PROCEEDINGS

\subsection{Court jurisdiction}

When initiating an action for material claims, one of which is the claim of pecuniary compensation, or non-pecuniary loss compensation 
the court ratione materiae jurisdiction depends upon the value of the dispute subject-matter, and thus the amount claimed. The value of the dispute subject-matter is counted without interest and costs demanded in addition to the main claim (Article 20 of the CCP), so depending on the amount of the main claim, the district court is competent to hear the case at first instance when the value of the subject-matter of the dispute does not exceed PLN 75,000 but if it is higher, then, the case belongs to the jurisdiction of the regional court.

Starting the proceedings, the travellers may choose between general local venue and bring their action, according to the defendant's place of residence or seat (Art. 27, Art. 28 and Art. 30 of the CCP) or apply the alternate court competence, bringing the claim against an entrepreneur before the court in whose region the main plant or branch is located, if the claim is related to the operation of this plant or branch (Art. 33 of the CCP). In turn, an action for the conclusion of a contract, establishing its content, for its amending and for establishing the existence of a contract, for its performance, termination or annulment, as well as for compensation of non-performance or improper performance of the contract may be initiated before a court of the place of contract performance (Article $34 \$ 1$ of the CCP). On the other hand, an action for a claim, arising out of tort may be brought before the court in whose region the event which caused the damage occurred (Article 35 of the CCP).

\subsection{Formal and fiscal conditions of the action}

To initiate an action successfully, it is necessary to meet the formal conditions of the lawsuit, including the general formal conditions of the procedural writ under Art. 126 of the CCP and elements characteristic for this very writ, i.e. precisely specified pleadings and an indication of the facts on which the claimant bases their pleas (Article $187 \$ 1$ of the CCP). The claim pleadings set out the scope of legal protection sought by the claimant, which the court is bound by when examining the case (Art. $321 \S 1$ of the CCP $)^{46}$. A claim must be paid, depending on the value of

46 K. Weitz (2011), Związanie sądu granicami żądania w procesie cywilnym [The court being bound by the pleadings in the civil proceedings], In: Aurea Praxis Aurea 
the subject of the dispute, which in the event of a claim for damages is the amount of money claimed by the claimant (Article 13 of the C.C.). A party that is not able to bear the costs without prejudice to themselves and the family may, of course, request an exemption from court costs by submitting a property declaration form that will allow the court to assess the justification of the application submitted by the claimant (Article 102 of the ACCCC).

\subsection{Subjective and objective scope of proceedings}

A passenger bringing an action shall decide against whom they are pleading, e.g. claiming a delayed flight - against the tour operator or against the carrier. The correct identification of the defendant, its organizational and legal form included, is necessary, from the point of view of the formal prerequisites of the statement of claims, assessment of the defendant's legal and procedural capacity, as well as, for the assessment of the defendant's capacity to be a party to proceedings. Incorrectly identifying the defendant an entity which is not the addressee of the traveller's claims will cause dismissal of the action.

Regardless of which of the claims the traveller chooses, they shall specify the pleadings which shall be binding for the court. The court may not adjudge on an object not covered by the pleadings nor judge above the pleadings (Article $321 \S 1$ of the CCP) ${ }^{47}$. To set out the amount of one or the other compensation is only seemingly easy. It is known that the compensation includes real damage to property (damnum emergens) and lost benefits (lucrum cessans), but what does this mean in practice? A traveller who was accommodated in a room of a lower standard shall determine the difference between the price of the room he was given and the room he had booked. This task seems feasible. However, it will be more

Theoria. Księga Pamiątkowa ku czci Profesora Tadeusza Erecińskiego [Commemorative book devoted to the memory of prof. Tadeusz Ereciński], vol. 1, K. Weitz, J. Gudowski, ed., Warszawa, 679 et seq.

47 J. Misztal-Konecka (2012), Zakaz wyrokowania ponad żądanie strony ('Ne eat iudex ultra petita partium') - rzymskie tradycje i współczesne regulacje polskiego procesowego prawa cywilnego [Prohibition to allow more than claimed by the party - Roman traditions and contemporary regulations of Polish civil law], Zeszyty Prawnicze, No. 12.4: 41 et seq. 
difficult if, for example, the event organizer did not carry out one of the trips that were on the package travel programme. Of course, the cost shall be determined, but in practice, it means that this information is held by the event organizer, and bringing an action, the traveller must specify the amount of the claim for compensation already at this stage, and therefore, in the content of the statement of claims. Without an obligation imposed on the defendant, the event organizer, to submit to the court pursuant to Art. $248 \$ 1$ of the CCP the information about the cost of the trip not effected, it is very difficult to set out precisely the loss suffered. When setting out the amount of compensation of non-pecuniary loss, a traveller will often be guided by their subjective feelings about the extent of harm, resulting from a spoiled holiday. The analysis of the case law of common courts in cases, concerning compensation of non-pecuniary loss, even if only for detriment to health, shows far-reaching differences, not so much in the evaluation of the prerequisites, affecting setting out the size of the damage, but its amount ${ }^{48}$. Similarly, in respect of a claim for non-pecuniary compensation of spoiled holiday, the loss of rest, the loss of pleasure from holiday, the harm suffered by the traveller will be evaluated by the court ad causam ${ }^{49}$.

The scope of the claims pursued is also under the impact of the traveller's decision whether they assert claims against the event organizer or the carrier. In the case, the traveller gets compensation or a price reduction for cancelled or delayed flights, train travel or boat voyage, the amounts of compensation claims or price lowering for spoiled holiday shall be correspondingly reduced (Article 50 subpara. 7 of the Act on package travel).

Theoretically, there are no restrictions, so the traveller can sue parallelly the carrier for a delayed or cancelled flight, and additionally the tour operator for "spoiled holiday", but they shall be aware that compensation obtained from one title affects the amount of the other claims asserted.

48 M. Nesterowicz, In: Prawo zobowiązań..., 1178. Confer also: SC’s judgements of $18^{\text {th }}$ December 1975, I CR 862/75, LEX No. 7781 and of $5^{\text {th }}$ December 2006, II PK 102/06, OSNP 2008, No. 1-2, item 11.

49 With reference to difficulties to prove the amount of non-pecuniary loss confer: A. Koronkiewicz-Wiórek (2009), Zmarnowany urlop w praktyce - kilka uwag na tle orzecznictwa sądów wrocławskich [Spoiled holiday in practice, a few comments at the background of Wrocław courts' judgements], Rejent, No. 6: 69 et seq. 
Article 50 subpara. 7 of the Act on package travel is consistent with the general rules, arising from the C.C., that damage, resulting from one event cannot be a source of enrichment.

Therefore, to assert non-pecuniary and pecuniary compensation for a delayed or cancelled flight or voyage included, against the tour operator seems a much better solution for the traveller. The tourism organizer is entitled to a recourse claim against any third party that has contributed to the event, causing a price reduction or resulting in the necessity to pay compensation referred to in Art. 50 subpara. 1 and 2 of the Act on package travel.

\subsection{Proceedings to take evidence}

Taking evidence is a very important stage for the outcome of the civil trial. The burden of proof (onus probandi) charges the claimant - they must prove the premises of the defendant's liability for damage, i.e. failure to perform or improper performance of the contract, occurrence of damage and an adequate causal link between the damage and the event that has caused it ${ }^{50}$. The court may, despite the damage suffered by the traveller, dismiss the action if the claimant fails to prove that the claim for pecuniary or non-pecuniary compensation is justified, i.e. when the damage is not in an adequate causal link with the non-performance or improper performance of the contract or when the claimant has not proved the damage or its amount ${ }^{51}$. This means that the traveller must try to gather evidence,

50 Confer: M. Wałachowska (2013), Odszkodowanie za niewykonanie lub nienależyte wykonanie umowy o podróż i zadośćuczynienie za "zmarnowany urlop” [Compensation for non-performance or improper performance of a travel contract and non-pecuniary loss compensation of spoiled holiday], In: Odpowiedzialność biur podróży a ochrona klientów w prawie polskim i Unii Europejskiej [Travel agencies' liability and protection of travellers in Polish and European Union Laws], M. Nesterowicz, ed., Toruń, 66.

51 The system of compensation liability shall also influence the shape of evidence-taking proceedings along with the range of liability of the tourism organizer. The same event may constitute the reason for tort and contract liability. More on the liability concurrence: M. Nesterowicz (2013), Podstawy i granice odpowiedzialności cywilnej biur podróży [The grounds and boundaries of travel agencies' liability], In: M. Nesterowicz, ed., Odpowiedzialność biur podróży a ochrona klientów w prawie polskim i Unii Europejskiej [Travel 
photos, videos, documents, and data of witnesses able to confirm the facts, justifying the claim, already during their spoiled holiday, for instance services of a lower standard accommodation, poorer quality of food, of service or other types of inconvenience associated with getting the so-called substitute benefits to replace those granted in the contract. Owing to the open catalogue of evidence, it is possible to demonstrate the validity of the claim by means of all available evidence. Given the nature of compensation claims, the recordings, photos and, of course, testimonies of witnesses in a position to confirm that the recordings of image and sound are those exactly showing the tourist event in question will be of great importance.

\subsection{Decision concluding the case}

In civil proceedings, the court rules in the form of a judgment on the substantive matters. It is also possible to render an order for payment in order proceedings, proceedings by writ of payment for minor amounts or electronic writ proceedings, if the claimant chooses to use one of these expedited proceedings and the case qualifies to be examined in these proceeding $5^{52}$. The order for payment is always a decision, granting the claim in full. By judgment, the court may allow the claim in whole or in part, dismiss the remainder or dismiss the claim in its entirety. An action may be dismissed not only when the action is unfounded, because the traveller failed to prove either the reasons for the claim, or its amount or did not justify the premises for liability for damage, or else the court was of the opinion that the damage suffered by the traveller was not in an adequate causal link with the damage event which had occurred. The court will also dismiss the action when the right to be sued is missing, i.e. when the action was addressed against the wrong person or the claimant's claim is time-barred.

Allowing the claim, the court will encounter the same doubts that the traveller themselves had to face while trying to set out the amount

agencies' liability and protection of travellers in Polish and European Union Laws], Toruń, 12 et seq.; M. Wałachowska, Odszkodowanie..., 69 et seq.

52 With the exception of the proceedings by writ for a lesser value on the application of which the court decides (Art. $201 \$ 1$ of the CCP). 
of damage. While the property claim is measurable, the harm suffered is invariably difficult to be valued. The jurisprudence of common courts has not yet developed a way to calculate non-pecuniary loss compensation that could provide travellers or their barristers with sui generis reference point to facilitate to establish its amount.

Analyzing the solutions adopted in the laws of other countries, it can be noticed that each time the general question of how the courts could compute damages for disappointment and loss of comfort was an issue. Common law damages are limited to consequences that are not too remote and damages will only be recoverable for losses that arise naturally from the breach or are actually contemplated as a probable result of the breach ${ }^{53}$. In common law countries, just as in countries with a continental legal system, determining the amount of compensation is also of an evaluative nature ${ }^{54}$.

The judgment in Jarvis $v$ Swans Tours had a breakthrough significance for the case law in common law states. The Court of Appeal in London awarded the traveller a compensation for wasted holidays which exceeded the value of the trip. From now on, it has been recognized that if the subject of the contract was to provide pleasure, relaxation and rest during the holidays, then the feeling of discomfort, inconvenience and nervousness should be considered as damage. It is treated as a breach of contract. Nowadays at common law, violations of contract are usually remedied by an award of damages ${ }^{55}$. This decision affected case law in other countries, e.g. Australia ${ }^{56}$.

In Germany, attempts to calculate the amount of compensation in appointment by the amount of remuneration were made by dividing the average monthly net income of the injured party by 30 days. The day rate was multiplied by the number of days of wasted vacation, thus obtaining the amount of compensation. Not all courts used this method of counting

53 Confer: Philip J. Evans, Spoiled Holidays: Damages for Disappointment or Distress, The Tourism Industry 2004, Vol. 6: 1; https://researchonline.nd.edu.au/cgi/viewcontent.cgi? referer $=$ \&httpsredir $=1$ \&article $=1012 \&$ context $=$ law_article $\quad[$ date of access: 20.03.2020]; M. Nesterowicz, Prawo..., 113.

54 Philip J. Evans, Spoiled..., 4.

55 Philip J. Evans, Spoiled..., 1; https://researchonline.nd.edu.au/cgi/viewcontent. cgi? referer $=$ \&httpsredir $=1$ \&article $=1012$ \&context=law_article [date of access: 20.03 .2020 ].

56 Philip J. Evans, Spoiled..., 3. 
because it made the amount of compensation for damages suffered during the same trip dependent on the amount of remuneration, leaving the issue open to those who are not employed ${ }^{57}$.

When trying to set out the amount of claim, the so-called Frankfurt Table ${ }^{58}$ could be used as a help. The table, commissioned by the Frankfurt am Main Court (Frankfurter Landgericht), is not binding even in Germany, but it is a sui generis benchmark how to calculate the amount of travellers' claims against German travel agencies. The table, in four sections, contains an open catalogue of benefits, in which were calculated per cents of hypothetical breaches with regard to, among other services, accommodation, meals, transport ${ }^{59}$. The Frankfurt table is also increasingly used in other countries, for instance in Austria and Poland ${ }^{60}$.

The court assesses the validity of claims for non-pecuniary loss and pecuniary damage compensation of a spoiled holiday, based on the facts of the given case analysed with the use of their knowledge and experience.

The proceedings for non-pecuniary loss or pecuniary damage compensation can also be concluded by the decision to discontinue the proceedings. This occurs either when the parties succeed in reaching a settlement in court or when the claimant successfully withdraws the lawsuit. The court's decision, concluding the case in an instance also contains a decision on the costs of the trial (Article 108 of the CCP). As a rule, in accordance with the principle of responsibility for the outcome of the trial, the losing party pays the costs of proceedings (Article 98 of the CCP), but if the action has been allowed in part, the court may correspondingly divide the costs of the process between the parties (Article 100 of the CCP), guided by the proportion of losing to winning.

57 More, confer: M. Nesterowicz, Prawo..., 110 et seq.

58 https://www.rechtspraxis.de/frankfurt.htm [date of access: 3.02.2020].

59 A. Chambellan (2013), Tabela frankfurcka jako wzorzec rozstrzygania sporów pomiędzy biurami podróży a klientami w Niemczech [The Frankfurt table as a benchmark to solve problems between travellers and travel offices], In: M. Nesterowicz, ed., Odpowiedzialność biur podróży a ochrona klientów w prawie polskim i Unii Europejskiej [Travel agencies' liability and protection of travellers in Polish and European Union Laws], Toruń, 126 et seq.

60 A. Chambellan, Tabela..., 130 et seq. 


\section{CONCLUSIONS}

Holidays, travel and leisure breaks are no longer the privilege of a limited group of people, but become a consumer product for a growing number of travellers. Nowadays holidays play an important role in life and effective enjoyment is value in its self, worth protecting. Due to the implementation of the Directive (EU) on package travel and linked travel arrangements 2015/2302 of the European Parliament and of the Council, similar legal solutions regarding compensation for wasted holidays will operate in the Member States. The Court of Justice of the European Union provides consistent interpretation of the EU law in all EU countries and its appliance by EU countries and institutions. The judicial decisions of the Court of Justice of the EU contributed to the gradual internalization of common values by domestic legal systems.

The polish Act on package travel and linked travel arrangements has been in force only since $1^{\text {st }}$ July, 2018, and it is too early to evaluate whether new legal instruments will facilitate travellers' claims for compensation of spoiled holidays. Transitory provisions provide that proceedings initiated and not concluded by the date of entry into force of the Act, i.e. by $1^{\text {st }}$ July, 2018, shall be conducted on the basis of the existing principles, i.e. in accordance with the solutions of the previous Act on tourist services (Article 73 of the Act on package travel). The case law in this area is relatively modest. Theoretically, the new regulation shall allow tourists to pursue at least some claims without having to go to court. There are appropriate legal instruments therefor. However, if it becomes necessary to pursue claims before a court, the traveller must properly prepare for this step by choosing an individual or group action. Certainly, the choice shall be preceded by an analysis of the costs of proceedings, the value of the evidence gathered, because the burden of proof charges the traveller who asserts claims for spoiled holiday, both in terms of evidence to prove the prerequisites for their right to compensation from the person responsible for the damage and its amount. Difficulties in proving the justification or amount of the claims, if any, have a direct impact on the outcome of the proceedings, the obligation to pay the costs of the trial or at least share them in a part included. 
At the moment, despite the existence of a clear substantive law basis to claim for compensation of spoiled holidays, the courts take into account the actions of those wronged, granting compensation, but these amounts are relatively low. It shall be expected that the amounts awarded by courts for non-pecuniary compensation of spoiled holidays will keep growing each year until they reach average European compensation rates. We will be looking forward to see the courts' approach to awarding the amount of non-pecuniary loss compensation, which may, after all, exceed the value of the trip itself.

\section{REFERENCES}

Asłanowicz M. (2019), Ustawa o dochodzeniu roszczeń w postępowaniu grupowym. Komentarz, Warszawa: C.H. Beck.

Bagińska E., Osowska-Kowalska A. (2013), Dyrektywa 90/314/EWG o podróżach turystycznych - perspektywy zmian, In: M. Nesterowicz, ed., Odpowiedzialność biur podróży a ochrona klientów w prawie polskim i Unii Europejskiej, Toruń: Wyższa Szkoła Bankowa w Toruniu, 23-40.

Botiuk-Filip M. (2019), Problematyka odpowiedzialności turystycznych biur podróży za poniesione przez podróżnych szkody majątkowe i niemajątkowe, Przegląd Ustawodawstwa Gospodarczego, No. 3: 15-18.

Chambellan A. (2013), Tabela frankfurcka jako wzorzec rozstrzygania sporów pomiędzy biurami podróży a klientami w Niemczech, In: M. Nesterowicz, ed., Odpowiedzialność biur podróży a ochrona klientów w prawie polskim i Unii Europejskiej, Toruń: Wyższa Szkoła Bankowa w Toruniu, 125-135.

Ciemiński M. (2005), Naprawienie uszczerbku polegającego na utraconej przyjemności z podróży, Kwartalnik Prawa Prywatnego, No. 2, 356-391.

Evans P.J. (2004), Spoiled Holidays: Damages for Disappointment or Distress, The Tourism Industry 2004, Vol. 6: 1-7.

Gajda-Roszczynialska K. (2012), Sprawy o ochronę indywidualnych interesów konsumentów w postępowaniu cywilnym, Warszawa: Wolters Kluwer Polska SA.

Gołaczyński J., Szostek D., ed. (2019), Kodeks postępowania cywilnego. Komentarz do ustawy z 4.7.2019 r. o zmianie ustawy - Kodeks postępowania cywilnego oraz niektórych innych ustaw, Warszawa: C.H. Beck.

Koronkiewicz-Wiórek A. (2009), Zmarnowany urlop w praktyce - kilka uwag na tle orzecznictwa sądów wrocławskich, Rejent, No. 6: 53-83. 
Kryla-Cudna K. (2018), Zadośćuczynienie pieniężne za szkodę niemajątkową powstałą wskutek niewykonania lub nienależytego wykonania umowy, Warszawa: C.H. Beck.

Kuska-Żak I. (2008), Odpowiedzialność organizatora turystyki za szkodę niemajątkową powstałą na skutek niewykonania lub nienależytego wykonania umowy o imprezę turystyczną, In: Turystyka a prawo. Aktualne problemy legislacyjne i konstrukcyjne, P. Cybula, J. Raciborski, ed., Sucha BeskidzkaKraków: Wyższa Szkoła Turystyki i Ekologii, 123-138.

Luzak J., Osajda K. (2005), Odpowiedzialność za zmarnowany urlop w prawie polskim, Kwartalnik Prawa Prywatnego, No. 2: 305-353.

Maciąg K. (2018), Ochrona podróżnego na tle ustawy o imprezach turystycznych i powiązanych usługach turystycznych oraz ustawy o usługach turystycznych - analiza porównawcza, IKAR, No. 4, Legalis.

Misztal-Konecka J. (2012), Zakaz wyrokowania ponad żądanie strony ('Ne eat iudex ultra petita partium') - rzymskie tradycje i współczesne regulacje polskiego procesowego prawa cywilnego, Zeszyty Prawnicze, No. 12.4: 41-56.

Nesterowicz M. (1988), Glosa do uchwały z dnia 25 lutego 1986 r., III CZP 2/86, Nowe Prawo, No. 9: 108-114.

Nesterowicz M. (1996), Dyrektywa Rady Wspólnot Europejskich o podróżach turystycznych a prawo polskie, Kwartalnik Prawa Prywatnego, No. 3: 435-445.

Nesterowicz M. (2002), Zadośćuczynienie pieniężne za "zmarnowany urlop" podczas wycieczki turystycznej, Państwo i Prawo, No. 10: 72-76.

Nesterowicz M. (2011), Odpowiedzialność cywilna biur podróży w prawie francuskim, Państwo i Prawo, No. 2: 34- 46.

Nesterowicz M. (2011), Odpowiedzialność cywilna biura podróży za "zmarnowany urlop" w prawie polskim i porównawczym (na tle uchwały Sądu Najwyższego z 19 listopada 2010 r.), Przegląd Sądowy, No. 5: 5-15.

Nesterowicz M. (2013), Podstawy i granice odpowiedzialności cywilnej biur podróży, In: M. Nesterowicz, ed., Odpowiedzialność biur podróży a ochrona klientów w prawie polskim i Unii Europejskiej, Toruń: Wyższa Szkoła Bankowa w Toruniu, 7-22.

Nesterowicz M. (2016), Prawo turystyczne, Warszawa: Wolters Kluwer Polska SA. Nesterowicz M. (2018), Dyrektywa Unii Europejskiej o imprezach turystycznych i powiązanych usługach turystycznych, jej implementacja do prawa polskiego i odpowiedzialność biur podróży, Przegląd Sądowy, No. 9: 44-57.

Nesterowicz M. (2018), In: Prawo zobowiązań - część szczegółowa. System Prawa Prywatnego, Vol. 7, J. Rajski, ed., Warszawa: C.H. Beck.

Peiper L. (1934), Kodeks zobowiązań, Kraków: Leon Frommer. 
Piskozub P. (2015), Reklamacja imprezy turystycznej, Edukacja Prawnicza, No. 1: 22-25.

Siedlecki, G. (2014), Zadośćuczynienie za zmarnowany urlop, Studenckie Zeszyty Naukowe, No. 24: 39-45.

Sieradzka M. (2018), Dochodzenie roszczeń w postępowaniu grupowym. Komentarz, Warszawa: Wolters Kluwer Polska SA.

Tomaszek A. (2010), Pełnomocnik powoda w polskim postępowaniu grupowym, Monitor Prawniczy, No. 12: 666-670.

Wałachowska M. (2013), Odszkodowanie za niewykonanie lub nienależyte wykonanie umowy o podróż i zadośćuczynienie za "zmarnowany urlop", In: M. Nesterowicz, ed., Odpowiedzialność biur podróży a ochrona klientów w prawie polskim i Unii Europejskiej, Toruń: Wyższa Szkoła Bankowa w Toruniu, 65-86.

Weitz K. (2011), Związanie sądu granicami żądania w procesie cywilnym, In: Aurea Praxis Aurea Theoria. Księga Pamiątkowa ku czci Profesora Tadeusza Erecińskiego, Vol. 1, K. Weitz, J. Gudowski, ed., Warszawa, 679-715.

Zasuwik P. (2016), Odpowiedzialność organizatora turystyki za szkodę niemajątkową klienta w postaci tzw. zmarnowanego urlopu - glosa - III CZP 79/10, Monitor Prawniczy, No. 24: 1329-1333. 
